See discussions, stats, and author profiles for this publication at: https://www.researchgate.net/publication/317817266

\title{
Effects of intravenous lipopolysaccharide administration on feed intake, ruminal forage degradability, and liquid parameters and physiological responses in beef cattle
}

Article in Journal of Animal Science · July 2017

DOI: $10.2527 /$ jas.2017.1502

\section{CITATIONS}

3

5 authors, including:

Katana Lippolis

Oregon State University

19 PUBLICATIONS 16 CITATIONS

SEE PROFILE

Sevis

Kelsey Schubach

Texas A\&M University

26 PUBLICATIONS 27 CITATIONS

SEE PROFILE

Some of the authors of this publication are also working on these related projects:
READS

35

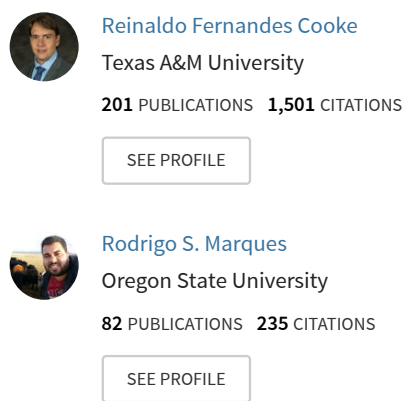

Physiologic, health, and production responses of dairy cows supplemented with an immunomodulatory feed ingredient during the transition period View project 


\title{
Effects of intravenous lipopolysaccharide administration on feed intake, ruminal forage degradability, and liquid parameters and physiological responses in beef cattle
}

\author{
K. D. Lippolis, R. F. Cooke, ${ }^{1,2}$ K. M. Schubach, R. S. Marques, and D. W. Bohnert \\ Oregon State University - Eastern Oregon Agricultural Research Center, Burns 97720
}

\begin{abstract}
This experiment compared DMI, ruminal forage degradability, and liquid parameters as well as physiological responses in beef cattle receiving a lipopolysaccharide (LPS) challenge or not. Eight ruminally cannulated Angus $\times$ Hereford steers $(485 \pm 16 \mathrm{~kg} \mathrm{BW})$ were housed in individual pens on $\mathrm{d}-7$, ranked by $\mathrm{BW}$, and allocated to 1 of 2 treatments administered on $\mathrm{d} 0: 1$ ) an intravenous (i.v.) bolus dose $(0.5 \mu \mathrm{g} / \mathrm{kg}$ of $\mathrm{BW}$, diluted in $5 \mathrm{~mL}$ of $0.9 \%$ sterile saline) of bacterial LPS (Escherichia coli $0111: \mathrm{B} 4)$ or 2) a $5-\mathrm{mL}$ i.v. injection of $0.9 \%$ sterile saline (CON). Steers had free-choice access to mixed alfalfa-grass hay, water, and a commercial vitamin + mineral mix during the experiment $(\mathrm{d}-7$ to 6). Hay DMI was evaluated daily from $d-5$ to 6 . Immediately prior to treatment administration (h 0 ), polyester bags containing $4 \mathrm{~g}$ of ground dietary hay (DM basis) were immersed into the rumen of each steer and incubated for $0,4,8,12,24,36$, and $48 \mathrm{~h}$ for DM and NDF degradability evaluation. Steers were also intraruminally pulse-dosed with $5 \mathrm{~g}$ of Co-EDTA immediately prior to treatment administration, and rumen fluid samples were collected at $0,2,4,6,8,12$, 16 , and $24 \mathrm{~h}$ for ruminal liquid volume and dilution rate calculations. Blood was collected every $2 \mathrm{~h}$ from
\end{abstract}

-2 to $8 \mathrm{~h}$, every $4 \mathrm{~h}$ from 8 to $16 \mathrm{~h}$, every $12 \mathrm{~h}$ from 24 to $72 \mathrm{~h}$, and every $24 \mathrm{~h}$ from 96 to $144 \mathrm{~h}$ relative to treatment administration. Values obtained before treatment administration were used as a covariate within each respective analysis. Steers receiving LPS had less $(P \leq 0.03)$ DMI on $\mathrm{d} 0$ and 1 compared with CON steers. Steers receiving LPS had reduced $(P \leq$ $0.05)$ rumen liquid volume and dilution rate as well as ruminal disappearance rate and effective degradability of DM and NDF compared with CON steers. Steers receiving LPS had greater $(P \leq 0.05)$ plasma tumor necrosis factor $\alpha$ at $2 \mathrm{~h}$, greater plasma haptoglobin from 24 to $72 \mathrm{~h}$, greater plasma cortisol from 12 to $16 \mathrm{~h}$, greater serum NEFA from 6 to $48 \mathrm{~h}$, greater plasma insulin and glucose at $2 \mathrm{~h}$, reduced plasma glucose from 4 to $12 \mathrm{~h}$, greater plasma cholecystokinin at $16 \mathrm{~h}$, and greater plasma leptin concentrations at $8,12,16,36,48$, and $60 \mathrm{~h}$ after treatment administration compared with CON steers. Hence, LPS administration transiently reduced DMI in steers via physiological reactions that modulate gastrointestinal motility and satiety centers in the central nervous system, in addition to potential host-microbiome endocrine interactions that impaired ruminal hay DM and NDF degradability.

Key words: beef cattle, inflammation, lipopolysaccharide, physiology, rumen function

\section{INTRODUCTION}

\footnotetext{
${ }^{1}$ Corresponding author: reinaldo.cooke@oregonstate.edu.

${ }^{2}$ Reinaldo Cooke is also affiliated as graduate professor to the Programa de Pós-Graduação em Zootecnia/Faculdade de Medicina Veterinária e Zootecnia, UNESP - Univ. Estadual Paulista, Botucatu, SP, Brazil, 18618-970.

Received February 22, 2017.

Accepted May 9, 2017.
}

The innate immune response plays a vital role in the organism's defense against disease and trauma and includes the synthesis of hepatic acute-phase proteins in response to proinflammatory cytokines (Carroll and Forsberg, 2007). The acute-phase protein response is also triggered by stressful manage- 
ment procedures such as weaning and road transport (Cooke, 2017) and has been observed to be detrimental to beef cattle performance (Johnson, 1997). Indeed, circulating concentrations of acute-phase proteins were negatively associated with ADG in cattle (Qiu et al., 2007) due to decreased DMI (Araujo et al., 2010), although the exact mechanisms for this latter outcome are not fully understood.

Rodrigues et al. (2015b) reported a transient decrease in DMI of beef cattle vaccinated against respiratory pathogens, which is known to stimulate the acute-phase response for proper acquirement of protective immunity (Tizard, 2004). Authors attributed these results to metabolic and inflammatory components that impact satiety and digestive tract function, such as cortisol, tumor necrosis factor $\alpha(\mathrm{TNF} \alpha)$, insulin, and leptin (Klasing and Korver, 1997; Allen et al., 2009) as well as physical regulators of DMI including ruminal digestibility, motility, and passage rate (Allison, 1985; Allen, 2000).

The impacts of inflammatory and acute-phase responses on ruminal digestive function, however, still require investigation (Rodrigues et al., 2015b). One strategy to elicit the bovine acute-phase protein response and investigate such parameters is via lipopolysaccharide (LPS) administration (Carroll et al., 2009). Hence, we hypothesized that LPS administration to cattle impacts rumen function and metabolic regulators of voluntary feed intake, resulting in decreased DMI. To test this hypothesis, this experiment compared DMI, ruminal forage degradability, and liquid parameters as well as physiological and inflammatory responses in beef cattle administered LPS or not.

\section{MATERIALS AND METHODS}

This experiment was conducted at the Oregon State University - Eastern Oregon Agricultural Research Center (Burns station). All animals were cared for in accordance with acceptable practices and experimental protocols reviewed and approved by the Oregon State University, Institutional Animal Care and Use Committee (number 4891).

\section{Animals and Treatments}

Eight halter-trained, ruminally cannulated Angus $\times$ Hereford steers were used in this experiment $(\mathrm{d}-7$ to 6). During the experiment, steers were housed in an enclosed barn in individual pens ( 3 by $5 \mathrm{~m}$ ) with freechoice access to mixed alfalfa-grass hay, water, and a commercial vitamin + mineral mix (Cattleman's Choice; Performix Nutrition Systems, Nampa, ID) containing $14 \% \mathrm{Ca}, 10 \% \mathrm{P}, 16 \% \mathrm{NaCl}, 1.5 \% \mathrm{Mg}, 3,200 \mathrm{mg} /$ $\mathrm{kg}$ of Cu, $65 \mathrm{mg} / \mathrm{kg}$ of I, $900 \mathrm{mg} / \mathrm{kg}$ of Mn, $140 \mathrm{mg} / \mathrm{kg}$ of Se, $6,000 \mathrm{mg} / \mathrm{kg}$ of $\mathrm{Zn}, 136,000 \mathrm{IU} / \mathrm{kg}$ of vitamin A, $13,000 \mathrm{IU} / \mathrm{kg}$ of vitamin $\mathrm{D}_{3}$, and $50 \mathrm{IU} / \mathrm{kg}$ of vitamin $\mathrm{E}$.

Steers were weighed daily from $\mathrm{d}-3$ to -1 of the experiment, and values were averaged as initial BW $(485 \pm 16 \mathrm{~kg})$. On d $0(0700 \mathrm{~h})$, steers were ranked by BW and assigned to 1 of 2 treatments (h 0$)$ : 1 ) an intravenous (i.v.) bolus dose of bacterial LPS $(0.5 \mu \mathrm{g} / \mathrm{kg}$ of BW; Escherichia coli 0111:B4; Sigma-Aldrich Corp., St. Louis, MO) or 2) a 5-mL i.v. injection of $0.9 \%$ sterile saline (CON). Bacterial LPS was dissolved into 5-mL of $0.9 \%$ saline immediately before administration and infused using 10-mL sterile syringes (Monoject; Covidien Animal Health, Mansfield, MA) according to initial cattle BW.

\section{Hay Intake and Ruminal Forage Disappearance}

Hay DMI was evaluated daily from $d-5$ to 6 by weighing and collecting samples of the offered and unconsumed feed at $0730 \mathrm{~h}$. All samples were dried for $96 \mathrm{~h}$ at $50^{\circ} \mathrm{C}$ in forced-air ovens for DM calculation. Hay daily DMI was calculated as kilograms per steer or based on percent of initial BW.

Immediately before treatments were administered, Dacron bags $(50 \pm 10 \mu \mathrm{m}$ pore size and 10 by $20 \mathrm{~cm}$ bag size; Ankom Technology Corp., Fairport, NY) containing $4 \mathrm{~g}$ (DM basis) of ground dietary hay (2-mm screen; Wiley Mill, model 4; Arthur H. Thomas, Philadelphia, PA) were suspended into the ruminal ventral sac of each steer and incubated in triplicate for $0,2,4,6,8,12,24$, and $48 \mathrm{~h}$ relative to treatment administration (h 0 ). Before ruminal incubation, all bags were soaked in warm water $\left(39^{\circ} \mathrm{C}\right)$ for $15 \mathrm{~min}$. After ruminal incubation, bags were repeatedly washed with running water until the rinse water was colorless and subsequently dried for 96 $\mathrm{h}$ at $50^{\circ} \mathrm{C}$ in a forced-air oven. The 0 -h bags were not incubated in the rumen but were subjected to the same soaking, rinsing, and drying procedures applied to the ruminally incubated bags. Dried samples were weighed for residual DM determination, and triplicates were combined and analyzed for NDF (Robertson and Van Soest, 1981) using procedures modified for use in an Ankom 200 Fiber Analyzer (Ankom Technology Corp.). Effective degradability of hay DM and NDF were calculated by fixing ruminal passage rate at $0.046 / \mathrm{h}$ (Poore et al., 1990) and using the model proposed by Ørskov and McDonald (1979).

\section{Liquid Dilution Rate and Volume}

Immediately before treatments were administered (h 0 ), each steer was intraruminally pulse-dosed with $5 \mathrm{~g}$ of Co-EDTA in a $150-\mathrm{mL}$ aqueous solution (Udén 
et al., 1980) via a stainless-steel probe with a perforated tip. Ruminal fluid samples (approximately 100 $\mathrm{mL}$ ) were collected by suction strainer (Raun and Burroughs, 1962) immediately prior to and at 2, 4, $6,8,12,16$, and $24 \mathrm{~h}$ after treatment administration. Twenty milliliters of ruminal fluid was stored $\left(-20^{\circ} \mathrm{C}\right)$ until analysis of Co concentration by atomic absorption using an air/acetylene flame (model $351 \mathrm{AA} / \mathrm{AE}$ Spectrophotometer; Instrumentation Laboratory, Inc., Lexington, MA). Ruminal liquid volume and liquid dilution rate were estimated by regressing the natural logarithm of Co concentration against sampling time as previously described by Warner and Stacy (1968).

\section{Sampling and Analysis}

Samples of dietary hay were collected weekly on $\mathrm{d}-7,0$, and 6; pooled across days; and analyzed for nutrient content by a commercial laboratory (Dairy One Forage Laboratory, Ithaca, NY). All samples were analyzed by wet chemistry procedures for concentrations of CP (method 984.13; AOAC, 2006), ADF (method 973.18 modified for use in an Ankom 200 fiber analyzer; Ankom Technology Corp.; AOAC, 2006), and NDF (Van Soest et al., 1991; modified for use in an Ankom 200 fiber analyzer; Ankom Technology Corp.). Calculations for TDN used the equation proposed by Weiss et al. (1992), whereas NEm and $\mathrm{NEg}$ were calculated with the equations proposed by the NRC (2000). Hay nutritional profile was (DM basis) $59 \% \mathrm{TDN}, 58 \% \mathrm{NDF}, 42 \% \mathrm{ADF}, 1.19 \mathrm{Mcal} / \mathrm{kg}$ of $\mathrm{NEm}, 0.62 \mathrm{Mcal} / \mathrm{kg}$ of NEg, and $10.9 \% \mathrm{CP}$.

Blood samples were collected every $2 \mathrm{~h}$ from -2 to $8 \mathrm{~h}$, every $4 \mathrm{~h}$ from 8 to $16 \mathrm{~h}$, every $12 \mathrm{~h}$ from 24 to $72 \mathrm{~h}$, and every $24 \mathrm{~h}$ from 96 to $144 \mathrm{~h}$ relative to treatment administration (h 0 ). Samples were collected via jugular venipuncture into commercial blood collection tubes (Vacutainer, $10 \mathrm{~mL}$; Becton, Dickinson and Company, Franklin Lakes, NJ) containing no additive or containing 158 United States Pharmacopeia units of freeze-dried sodium heparin for serum and plasma collection, respectively. After collection, all blood samples were immediately placed on ice, centrifuged $\left(2,500 \times g\right.$ for $30 \mathrm{~min}$ at $\left.4^{\circ} \mathrm{C}\right)$ for plasma or serum harvest, and stored at $-80^{\circ} \mathrm{C}$ on the same day of collection.

Serum samples collected from -2 to $60 \mathrm{~h}$ relative to treatment administration were analyzed for NEFA concentrations (colorimetric kit HR Series NEFA-2; Wako Pure Chemical Industries, Ltd., Richmond, VA). Plasma samples collected from -2 to $60 \mathrm{~h}$ relative to treatment administration were analyzed for concentrations of glucose (colorimetric kit number G7521; Pointe Scientific, Inc., Canton, MI), leptin (bovine leptin ELISA kit number MBS2882780; MyBio-
Source.com, San Diego, CA), cholecystokinin (bovine cholecystokinin ELISA kit number MBS028118; MyBioSource.com), and cortisol and insulin (chemiluminescent enzyme immunoassay, Immulite 1000; Siemens Medical Solutions Diagnostics, Los Angeles, CA). Plasma samples collected from -2 to $8 \mathrm{~h}$ relative to treatment administration were analyzed for TNF $\alpha$ concentrations (bovine TNF- $\alpha$ ELISA kit number ELB-TNFa-1; RayBiotech, Inc., Norcross, GA), whereas all plasma samples were analyzed for haptoglobin concentrations (Cooke and Arthington, 2013). The intra- and interassay CV were 4.7 and $7.9 \%$, respectively, for haptoglobin; 2.5 and $4.3 \%$, respectively, for glucose; 2.6 and $10.6 \%$, respectively, for NEFA; 4.2 and $5.5 \%$, respectively, for cholecystokinin; and 2.1 and $4.0 \%$, respectively, for leptin. Plasma cortisol, insulin, and TNF $\alpha$ concentrations were analyzed within a single assay. The intra-assay $\mathrm{CV}$ was $7.9 \%$ for cortisol, $4.9 \%$ for insulin, and $2.3 \%$ for $\mathrm{TNF} \alpha$.

\section{Statistical Analysis}

All data were analyzed using the MIXED procedure of SAS (SAS Inst. Inc., Cary, NC) and Satterthwaite approximation to determine the denominator degrees of freedom for the tests of fixed effects. Steer was considered the experimental unit and steer(treatment) was used as a random variable. Kinetic parameters of forage DM and NDF disappearance were estimated using nonlinear regression procedures of SAS, as described by Vendramini et al. (2008). The model statement used for ruminal forage disappearance, liquid dilution rate, and rumen liquid volume contained the effect of treatment. The model statements used for hay intake and all blood variables contained the effects of treatment, time (day for DMI or hour for blood variables), and the resultant interaction. In addition, values obtained prior to treatment application (average daily DMI from $\mathrm{d}-5$ to -1 or averaged values from -2 and $0 \mathrm{~h}$ for blood variables) were included as an independent covariate in each respective analysis. The specified term for the repeated statement was day for DMI or hour for blood variables, steer(treatment) as subject, and the covariance structure used was firstorder autoregressive based on the Akaike information criterion. Results are reported as covariately adjusted least squares means and were separated using LSD. Significance was set at $P \leq 0.05$, and tendencies were determined if $P>0.05$ and $\leq 0.10$. Results are reported according to treatment effects if no interactions were significant or according to the highest-order interaction detected. 


\section{RESULTS}

\section{Pretreatment Results}

Average DMI from $\mathrm{d}-5$ to -1 and average concentrations of plasma glucose, cholecystokinin, and leptin prior to treatment application were significant covariates $(P \leq 0.03)$ within their respective analysis but did not differ $(P \geq 0.63)$ between LPS and CON steers (Table 1). Average concentrations of plasma insulin prior to treatment application was also a significant covariate $(P=0.02)$ within its analysis and tended $(P=0.06)$ to be greater in LPS steers than in CON steers (Table 1). Average concentrations of plasma cortisol, haptoglobin, TNF $\alpha$, and serum NEFA concentrations prior to treatment application were not significant covariates $(P$ $\geq 0.24)$ within each respective analysis and were simi$\operatorname{lar}(P \geq 0.19)$ between LPS and CON steers (Table 1).

\section{Intake and Rumen Variables}

A treatment $\times$ day interaction was detected $(P<$ 0.01 ) for DMI (Fig. 1). Steers receiving LPS had less ( $P$ $\leq 0.03$ ) DMI, expressed as kilograms per day or percent of BW, compared with CON steers on $\mathrm{d} 0$ and 1 of the experimental period (Fig. 1). No treatment differences $(P \geq 0.23)$ in DMI were detected from d 2 to 6 (Fig. 1).

Steers receiving LPS had a reduced rumen liquid dilution rate and liquid volume $(P \leq 0.05)$ compared with CON cohorts (Table 2) during the 24-h sampling period following treatment administration. Steers receiving LPS also had a reduced $(P \leq 0.05)$ ruminal disappearance rate and effective degradability of DM and NDF compared with CON cohorts (Table 2) during the 48-h sampling period following treatment administration. Accordingly, treatment $\times$ hour interactions were detected $(P \leq 0.02)$ for DM and NDF disappearance, as percent remaining of initial DM and NDF content, given that these variables were less $(P<0.01)$ in LPS steers than in CON steers from 4 to $12 \mathrm{~h}$ relative to treatment administration (Fig. 2).

\section{Physiological Variables}

Treatment $\times$ time interactions were detected $(P \leq$ 0.04 ) for plasma concentrations of TNF $\alpha$, haptoglobin, cortisol, insulin, leptin, and serum NEFA, and a tendency $(P=0.09)$ for such interaction was detected for plasma cholecystokinin concentrations.

Steers receiving LPS had greater $(P<0.01)$ plasma TNF $\alpha$ concentration at $2 \mathrm{~h}$, and greater $(P \leq 0.05)$ plasma haptoglobin concentrations from 24 to $72 \mathrm{~h}$ relative to treatment administration compared with CON steers (Fig. 3). Steers receiving LPS had greater $(P \leq 0.05)$ plasma cortisol concentrations from 2 to 16
Table 1. Intake, metabolic, inflammatory, and acutephase variables obtained from steers prior to treatment application 1,2

\begin{tabular}{|c|c|c|c|c|}
\hline Item & $\mathrm{CON}$ & LPS & SEM & $P$-value \\
\hline \multicolumn{5}{|l|}{ Hay DMI } \\
\hline as $\mathrm{kg} / \mathrm{d}$ & 14.2 & 14.5 & 1.3 & 0.90 \\
\hline as $\% \mathrm{BW}$ & 2.93 & 2.98 & 0.23 & 0.88 \\
\hline $\begin{array}{l}\text { Plasma tumor necrosis factor } \\
\text { alpha, } \mathrm{ng} / \mathrm{mL}\end{array}$ & 0.060 & 0.037 & 0.041 & 0.70 \\
\hline Plasma haptoglobin, $\mu \mathrm{g} / \mathrm{mL}$ & 80 & 112 & 23 & 0.36 \\
\hline Plasma cortisol, ng/mL & 21.1 & 26.3 & 8.0 & 0.66 \\
\hline Plasma glucose, mg/dL & 64.3 & 62.5 & 2.9 & 0.67 \\
\hline Plasma insulin, $\mu \mathrm{IU} / \mathrm{mL}$ & 3.95 & 6.82 & 0.87 & 0.06 \\
\hline Serum NEFA, $\mu$ Eq/L & 0.132 & 0.150 & 0.009 & 0.19 \\
\hline Plasma leptin, ng/mL & 1.80 & 2.95 & 1.59 & 0.63 \\
\hline Plasma cholecystokinin, $\mathrm{pg} / \mathrm{mL}$ & 17.2 & 18.7 & 2.5 & 0.70 \\
\hline \multicolumn{5}{|c|}{$\begin{array}{l}\left.{ }^{1} \text { Treatments were } 1\right) \mathrm{LPS}=\text { intravenous (i.v.) bolus dose }(0.5 \mu \mathrm{g} / \mathrm{kg} \text { of } \\
\mathrm{BW} \text {, diluted in } 5 \mathrm{~mL} \text { of } 0.9 \% \text { sterile saline) of bacterial lipopolysaccha- } \\
\text { ride }(\text { Escherichia coli } 0111: \mathrm{B} 4 \text {, Sigma-Aldrich Corp., St. Louis, MO) or } 2) \\
\mathrm{CON}=5 \text {-mL i.v. injection of } 0.9 \% \text { sterile saline. }\end{array}$} \\
\hline \multicolumn{5}{|c|}{$\begin{array}{l}{ }^{2} \text { Treatments were administered on } \mathrm{d} 0 \text {. Results represent average hay } \\
\text { DMI from } \mathrm{d}-5 \text { to }-1 \text { and averaged values from blood samples obtained at } \\
-2 \text { and } 0 \mathrm{~h} \text { relative to treatment application. }\end{array}$} \\
\hline
\end{tabular}

$\mathrm{h}$ and greater $(P<0.01)$ serum NEFA concentrations from 6 to $48 \mathrm{~h}$ relative to treatment administration compared with CON steers (Fig. 4). Steers receiving LPS also had greater $(P<0.01)$ plasma insulin and glucose concentration at $2 \mathrm{~h}$ but reduced $(P \leq 0.05)$ plasma glucose concentrations from 4 to $12 \mathrm{~h}$ relative to treatment administration compared with $\mathrm{CON}$ steers (Fig. 5). Steers receiving LPS had greater $(P<$ $0.01)$ plasma cholecystokinin concentration at $16 \mathrm{~h}$ and greater $(P \leq 0.05)$ plasma leptin concentrations at $8,12,16,36,48$, and $60 \mathrm{~h}$ relative to treatment administration compared with CON steers (Fig. 6).

\section{DISCUSSION}

Results from the DMI evaluation and blood samples collected prior to treatment administration (Table 1) indicate that overall nutritional and physiological status were similar between treatments groups (Rodrigues et al., 2015b). Nevertheless, including these parameters as independent covariates in each respective analysis accounted for inherent differences among steers prior to treatment administration, particularly plasma insulin concentrations (Jacobs et al., 2013).

\section{Intake and Rumen Variables}

Treatment effects detected for hay DMI support our hypothesis and agree with previous research reporting a transient decrease in voluntary feed intake following LPS administration (Steiger et al., 1999). 

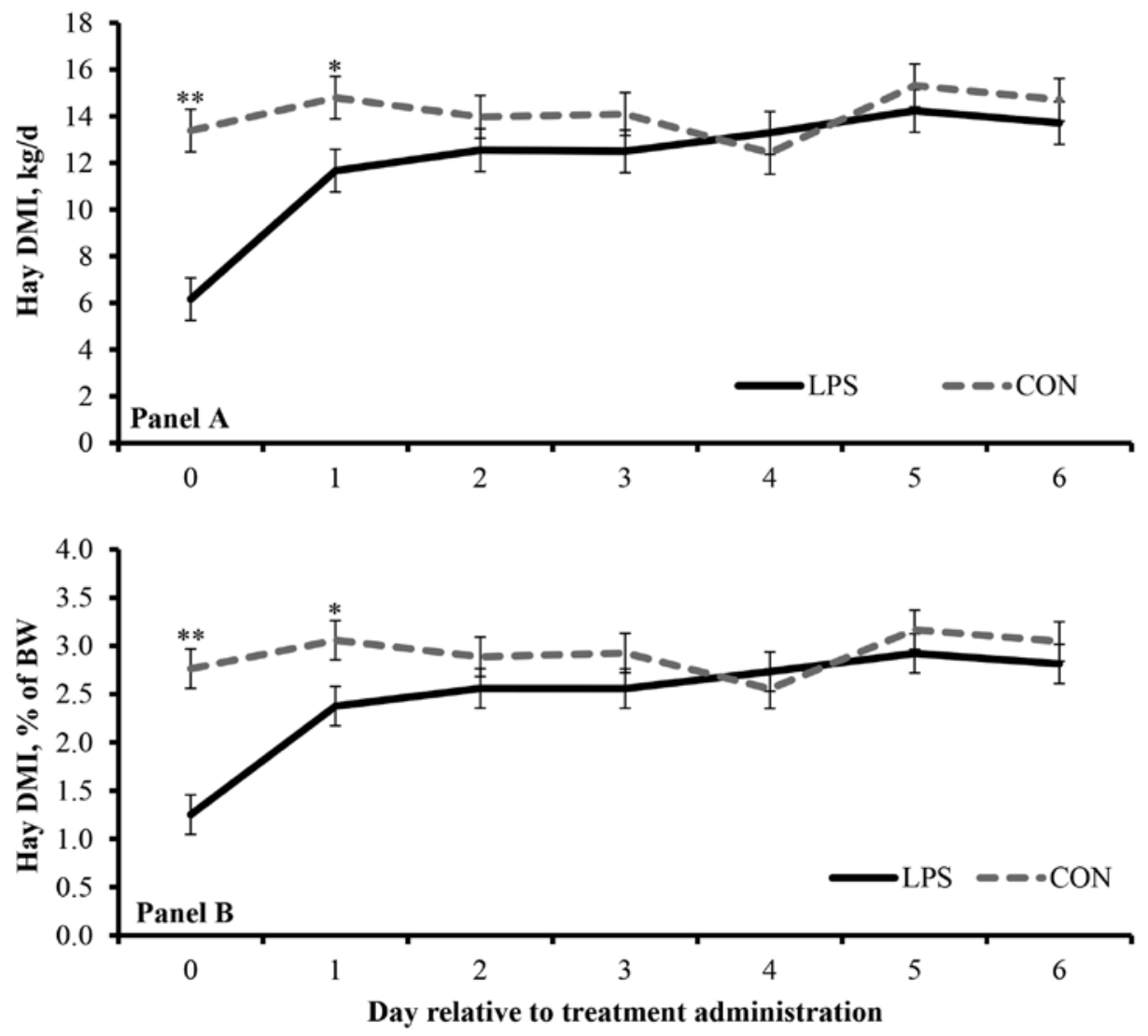

Figure 1. Hay DMI as kilograms per day (panel A) or percent of BW (panel B) of steers receiving 1) LPS $(n=4)=$ an intravenous (i.v.) bolus dose $(0.5 \mu \mathrm{g} / \mathrm{kg}$ of BW, diluted in $5 \mathrm{~mL}$ of $0.9 \%$ sterile saline) of bacterial lipopolysaccharide (Escherichia coli 0111:B4 [Sigma-Aldrich Corp., St. Louis, MO]) or 2) CON $(n=4)=$ a 5 -mL i.v. injection of $0.9 \%$ sterile saline. Treatments were administered on $\mathrm{d} 0$ at $0700 \mathrm{~h}$, and DMI was evaluated daily at $0730 \mathrm{~h}$. Hay daily DMI was calculated as kilograms per steer or based on percent of initial BW. Average hay DMI during the $5 \mathrm{~d}$ preceding treatment application served as covariate within each respective analysis. A treatment $\times$ day interaction was detected $(P<0.01)$. Treatment comparison by day; $* P=0.03 ; * * P<0.01$.

Rumen liquid dilution rate and liquid volume are directly associated with voluntary feed intake (Allison, 1985; Allen, 2000); hence, the LPS-induced decrease in these parameters corroborates the concurrent de-

Table 2. Rumen liquid dilution rate, rumen liquid volume, and ruminal in situ disappearance parameters of mixed alfalfa-grass hay in steers assigned to LPS $(n=$ 4) or 5-mL intravenous injection of $0.9 \%$ sterile saline $(\mathrm{CON} ; n=4)$

\begin{tabular}{lcccc}
\hline \hline Item & CON & LPS $^{1}$ & SEM & $P$-value \\
\hline Rumen liquid dilution rate, \%/h & 11.0 & 8.9 & 0.6 & 0.05 \\
Rumen liquid volume, $\mathrm{mL} / \mathrm{kg}$ of BW & 207 & 88 & 23 & 0.01 \\
Ruminal disappearance rate, \%/h & & & & \\
$\quad$ DM & 12.3 & 7.1 & 1.3 & 0.03 \\
$\quad$ NDF & 7.0 & 4.2 & 0.6 & 0.03 \\
Effective degradability, $\%$ & & & & \\
$\quad$ DM & 57.7 & 55.1 & 0.8 & 0.05 \\
NDF & 67.9 & 66.5 & 0.3 & 0.01 \\
\hline
\end{tabular}

${ }^{1} \mathrm{LPS}=$ intravenous bolus dose $(0.5 \mu \mathrm{g} / \mathrm{kg}$ of BW, diluted in $5 \mathrm{~mL}$ of $0.9 \%$ sterile saline) of bacterial lipopolysaccharide (Escherichia coli 0111:B4; Sigma-Aldrich Corp., St. Louis, MO).

${ }^{2}$ Calculated by fixing ruminal passage rate at $0.046 / \mathrm{h}$ (Poore et al., 1990) and using the model proposed by Ørskov and McDonald (1979). crease in hay DMI in LPS vs. CON steers. Administration of LPS decreases ruminal contractions and impairs rumen motility (Lohuis et al., 1988). Decreased ruminal motility is known to decrease ruminal passage rate of liquids and solids, which directly regulates feed intake (Allen, 2000). Supporting our results, others have also reported that LPS administration decreased DMI and ruminal passage rate of liquid and solids (Waggoner et al., 2009) and altered rumen fermentation characteristics such as $\mathrm{pH}$, VFA, and ammonia concentrations (Gilliam et al., 2009) in beef steers. In turn, the LPS-induced decrease in DMI may have further contributed to a decreased rumen liquid dilution rate and liquid volume in LPS steers by reducing the flow of saliva and fermentation substrates such as VFA and ammonia into the rumen (Adams and Kartchner, 1984). Water intake is also depressed by LPS administration (Plata-Salamán and Borkoski, 1993) and, although not evaluated herein, should also be considered as another cause for altered rumen fluid variables in LPS-administered steers (Teeter and Owens, 1983).

Research investigating heat stress also observed a decrease in DMI and passage rate; however, DM and 

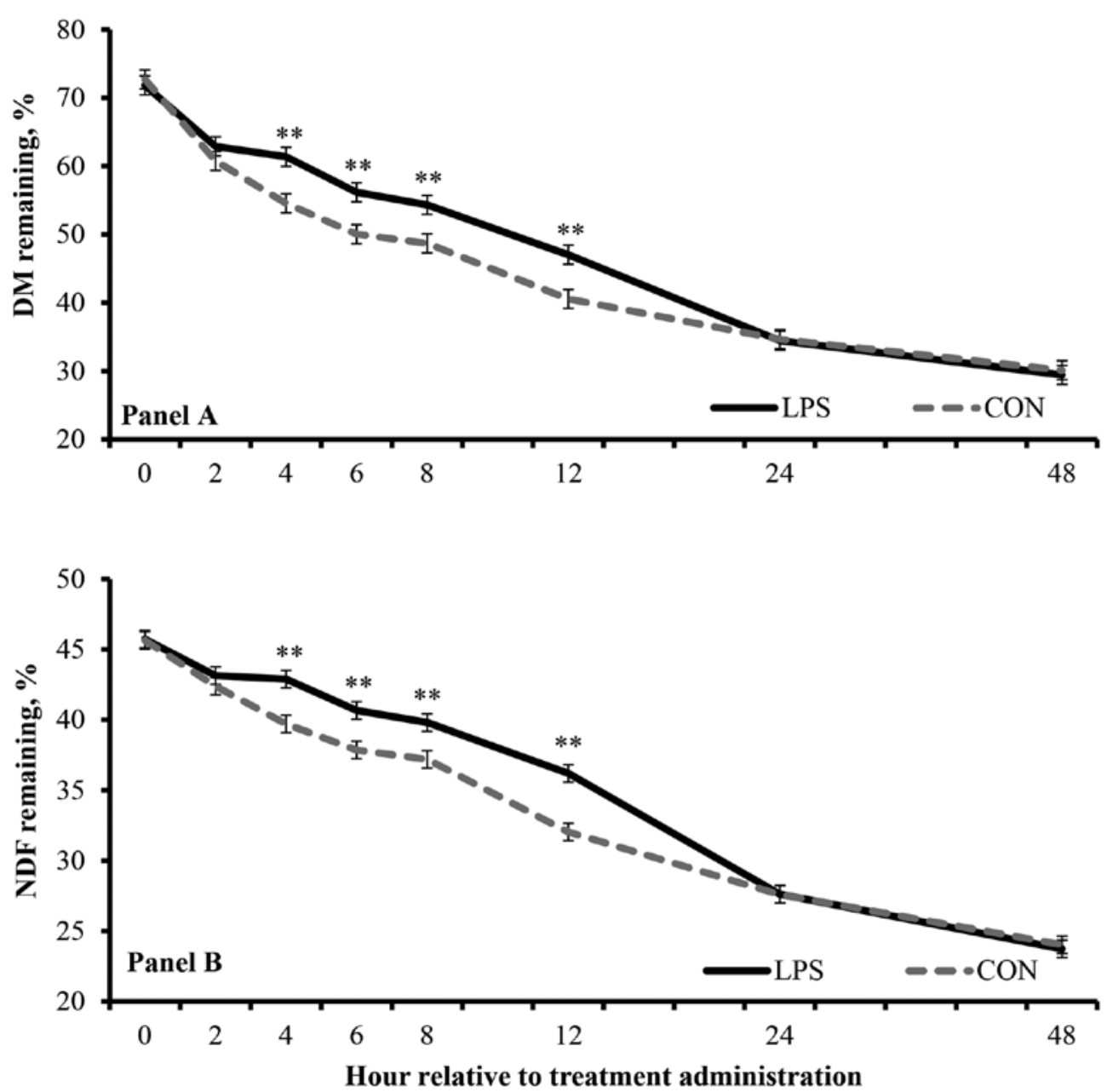

Figure 2. Ruminal hay DM (panel A) and NDF (panel B) disappearance, as percent remaining of initial DM and NDF content, of steers receiving 1) LPS $(n=4)=$ an intravenous (i.v.) bolus dose $(0.5 \mu \mathrm{g} / \mathrm{kg}$ of BW, diluted in $5 \mathrm{~mL}$ of $0.9 \%$ sterile saline) of bacterial lipopolysaccharide (Escherichia coli 0111:B4 [Sigma-Aldrich Corp., St. Louis, MO]) or 2) CON; $(n=4)=$ a 5-mL i.v. injection of $0.9 \%$ sterile saline. Treatments were administered at h 0. Treatment $\times$ hour interactions were detected $(P \leq 0.02)$. Treatment comparison by hour; $* * P<0.01$.

NDF digestibility were increased in heat-stressed dairy cattle (Bernabucci et al., 1999). In fact, reduced DMI, ruminal motility, and feed passage rate yields more time for ruminal feed digestion and increased ruminal volume (Farooq et al., 2010). In the present experiment, however, ruminal degradability of hay DM and NDF were reduced by LPS administration despite a decrease in ruminal motility and passage rate, as suggested by treatment differences on rumen volume and liquid dilution rate (Waggoner et al., 2009). Perhaps a potential decrease in water intake on LPS administration (PlataSalamán and Borkoski, 1993) limits ruminal fermentation whereas water intake is increased in heat-stressed cattle (NRC, 2000), although research is warranted to elucidate such contrasting outcomes. Nevertheless, results from this experiment are novel and suggest that LPS administration impacts not only DMI and ruminal motility but also feed degradability by rumen microbes.

\section{Physiological Variables}

Treatment differences reported for plasma TNF $\alpha$ and haptoglobin responses were expected based on neuroendocrine and innate immune responses elicited by LPS administration (Reuter et al., 2008; Carroll et al., 2009; Rodrigues et al., 2015b). Upon a pathogenic stimulus such as LPS administration, the innate immune system elicits several reactions with the intent of controlling or eliminating the infection (Abbas and Lichtman, 2007). These include synthesis of proinflammatory cytokines such as TNF $\alpha$, resulting in increased hepatic synthesis of acute-phase proteins including haptoglobin (Carroll and Forsberg, 2007; Carroll et al., 2009). Supporting treatment effects on hay DMI, $\mathrm{TNF} \alpha$ is known to reduce feed intake by modulating the central nervous and endocrine systems and inhibiting digestive function (Klasing and Korver, 1997) whereas plasma haptoglobin concentrations were negatively associated with DMI in feeder cattle (Qiu et al., 2007; Araujo et al., 2010). 

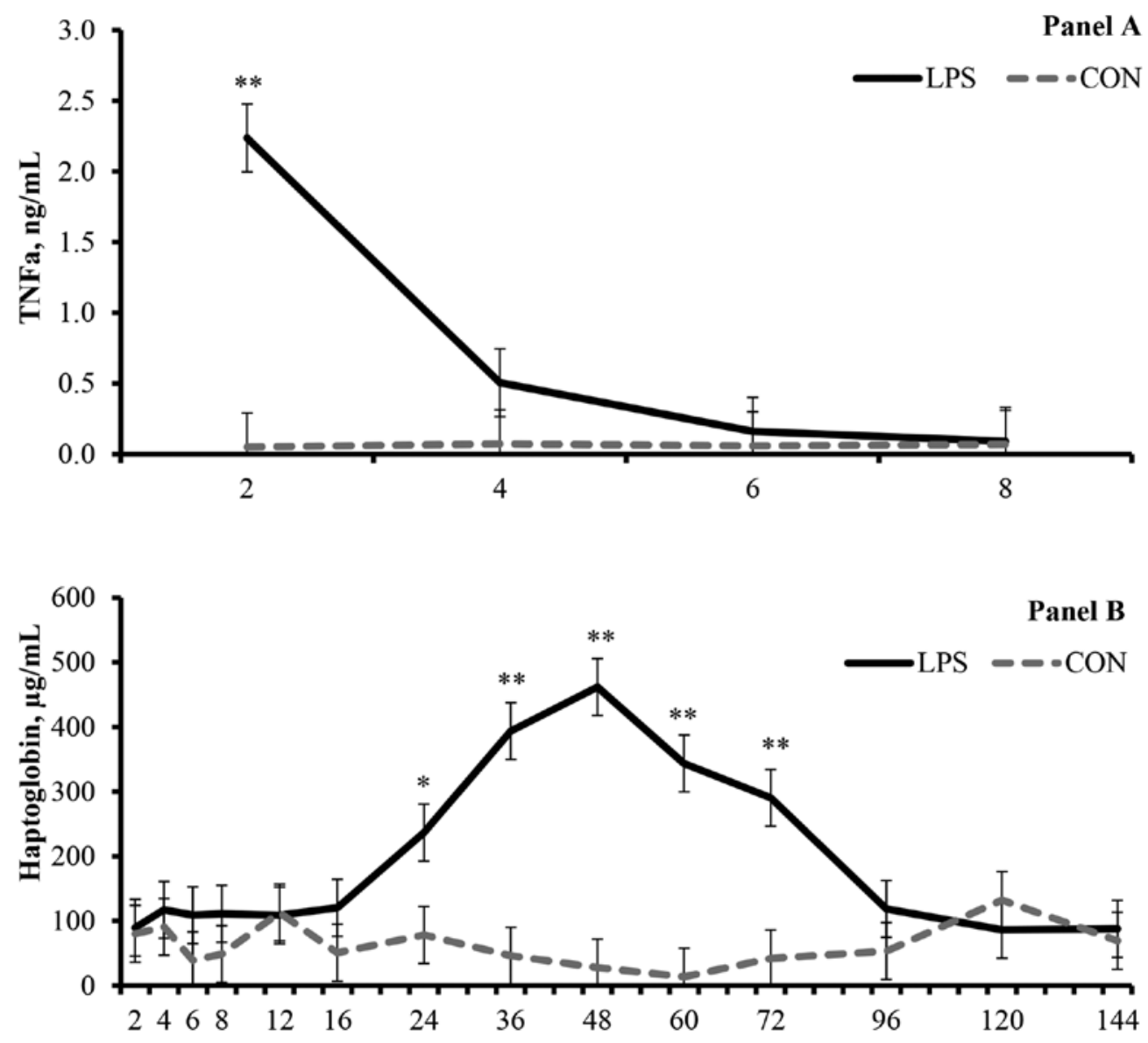

Hour relative to treatment administration

Figure 3. Plasma TNF $\alpha$ (TNFa; panel A) and haptoglobin (panel B) concentrations of steers receiving 1) LPS $(n=4)=$ an intravenous (i.v.) bolus dose $(0.5 \mu \mathrm{g} / \mathrm{kg}$ of BW, diluted in $5 \mathrm{~mL}$ of $0.9 \%$ sterile saline) of bacterial lipopolysaccharide (Escherichia coli 0111:B4 [Sigma-Aldrich Corp., St. Louis, MO]) or 2) $\mathrm{CON}(n=4)=$ a $5-\mathrm{mL}$ i.v. injection of $0.9 \%$ sterile saline. Treatments were administered at h 0 . Values obtained prior to treatment application $(-2$ and $0 \mathrm{~h}$ ) served as covariates within each respective analysis. Treatment $\times$ hour interactions were detected $(P<0.01)$. Within hour; ${ }^{*} P \leq 0.05 ; * * P<0.01$.

Circulating cortisol concentrations were also expected to increase on LPS administration, based on previous research from our and other research groups (Carroll et al., 2009; Rodrigues et al., 2015b). Cortisol modulates early physiological responses following a pathogenic stimulus, such as LPS administration, as an effector molecule on subsequent proinflammatory and acute-phase reactions (Carroll et al., 2009; Cooke et al., 2012). Cortisol is also known to act as a lipolytic agent during stress and immune reactions (Nelson and Cox, 2005) and indirectly impact voluntary feed intake (Allen et al., 2009). Accordingly, treatment differences on serum NEFA concentrations should be attributed to heightened lipolysis caused by the LPSinduced increase in circulating cortisol and other glucocorticoids and to the reduced feed intake of LPS vs. CON steers for $48 \mathrm{~h} \mathrm{(d} 0$ and 1) relative to treatment administration (Steiger et al., 1999; Waldron et al., 2003). Changes in circulating insulin and glucose concentrations on LPS stimuli have also been reported by others (Steiger et al., 1999; Waldron et al., 2003), with the intent of increasing energy utilization by the body to restore homeostasis (Eizirik et al., 1995; Andersson et al., 2001; Waggoner et al., 2009). Collectively, circulating concentrations of insulin, glucose, and NEFA have been associated with feed intake regulation in ruminants, particularly via the hepatic oxidation theory, with glucose and NEFA serving as oxidative substrates and suppressing feeding behavior in the brain (Foster et al., 1991; Allen, 2000; Allen et al., 2009).

Leptin synthesis by adipocytes is increased during an inflammatory response to modulate activation and maturation of leukocytes (Matarese et al., 2005; Fernández-Riejos et al., 2010; Rodrigues et al., 2015a), corroborating with treatment differences detected herein for this hormone. Leptin is also known to limit feed intake in ruminants by acting directly in satiety centers within the central nervous system (Houseknecht et al., 1998). To our knowledge, no other research has evaluated the impacts of i.v. LPS infusion on plasma cholecystokinin concentrations in cattle, which also modulates hypothalamic satiety centers 

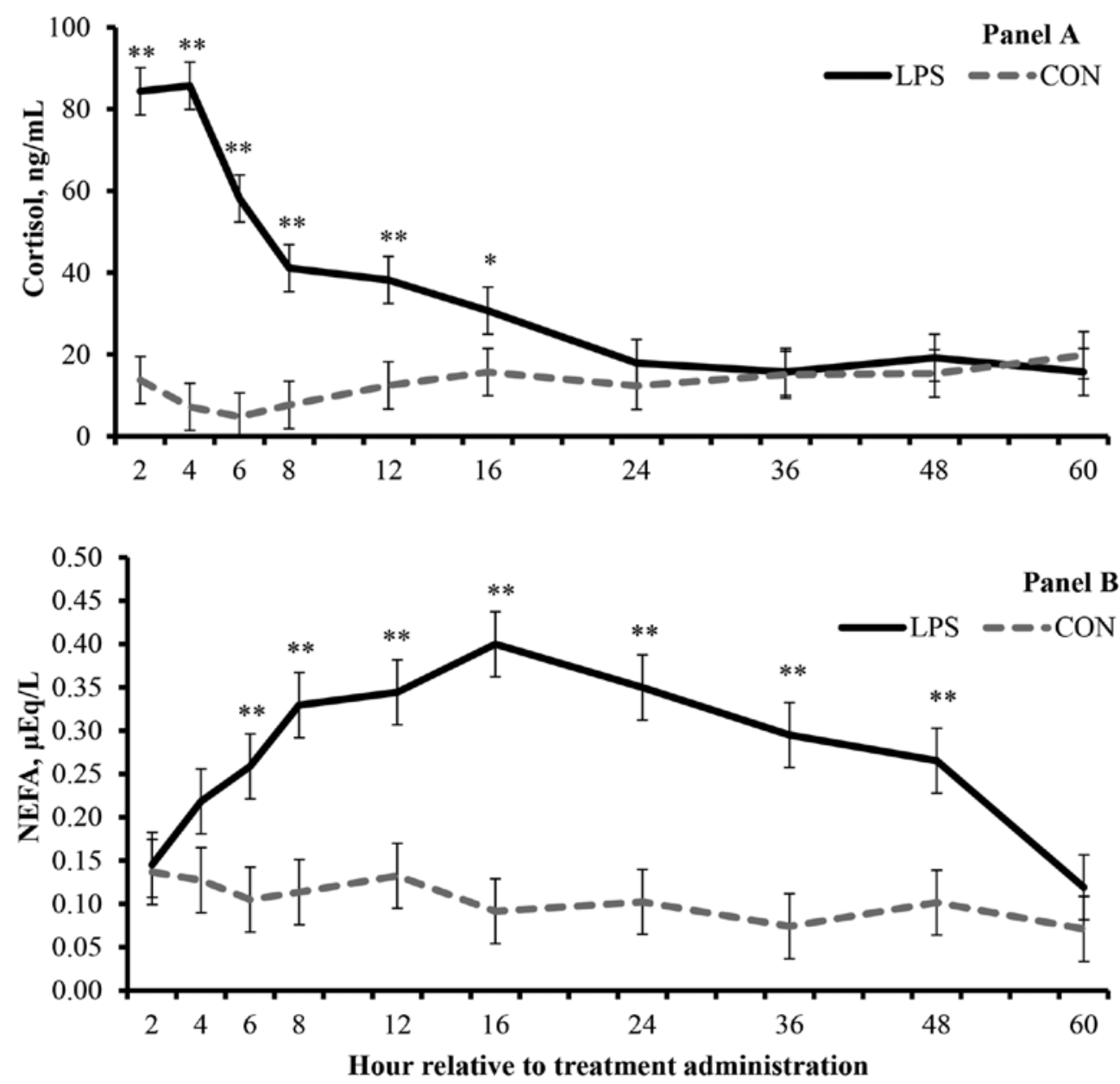

Figure 4. Plasma cortisol (panel A) and serum NEFA (panel B) concentrations of steers receiving 1) LPS $(n=4)=$ an intravenous (i.v.) bolus dose $(0.5 \mu \mathrm{g} / \mathrm{kg}$ of BW, diluted in $5 \mathrm{~mL}$ of $0.9 \%$ sterile saline) of bacterial lipopolysaccharide (Escherichia coli 0111:B4 [Sigma-Aldrich Corp., St. Louis, MO]) or 2) $\mathrm{CON}(n=4)=$ a 5 - $\mathrm{mL}$ i.v. injection of $0.9 \%$ sterile saline. Treatments were administered at h 0 . Values obtained prior to treatment application $(-2$ and $0 \mathrm{~h}$ ) served as covariates within each respective analysis. Treatment $\times$ hour interactions were detected $(P<0.01)$. Within hour; $* P \leq 0.05 ; * * P<0.01$.

(Crawley and Corwin, 1994). Nevertheless, Mani et al. (2012) suggested that circulating LPS and Toll-like receptor 4 , which recognizes bacterial endotoxin, activate enteroendocrine cells that synthesize cholecystokinin. Moreover, both leptin and cholecystokinin are known to synergistically limit gastrointestinal motility, resulting in satiety and reduced voluntary feed intake (Matson and Ritter, 1999).

\section{Overall Discussion}

In this experiment, LPS administration transiently reduced voluntary DMI in cattle. This outcome can be partially attributed to an LPS-induced increase in circulating concentrations of hormones and metabolites, such as TNF $\alpha$, NEFA, insulin, and glucose, that modulate DMI via satiety centers within the central nervous system (Klasing and Korver, 1997; Allen et al., 2009). Treatment effects on DMI should also be associated, with a cause and effect nature, with reduced ruminal liquid dilution rate and rumen volume in LPS vs. CON steers. These parameters are suggestive of decreased ruminal motility and passage rate in LPS steers (Waggoner et al., 2009) corroborated by increased plasma leptin and cholecystokinin, which are known to reduce gastrointestinal motility (Houseknecht et al., 1998; Matson and Ritter, 1999).

Reduced ruminal motility and feed passage rate, however, should result in increased ruminal degradability of hay DM and NDF (Bernabucci et al., 1999; Farooq et al., 2010). Yet treatment effects on ruminal degradability of hay DM and NDF suggest that LPS administration decreased feed degradability by rumen microbes. Tajima et al. (2007) reported a shift in rumen microbial composition and decreased VFA production in heat-stressed dairy cattle, indicating that stress conditions may impair rumen microbial function and consequent feed degradability. During stress and inflammatory challenges such as LPS administration, salivary concentrations of cortisol and proinflammatory cytokines are immediately increased (Miller et al., 2010; Rahman et al., 2010; Escribano et al., 2014). 

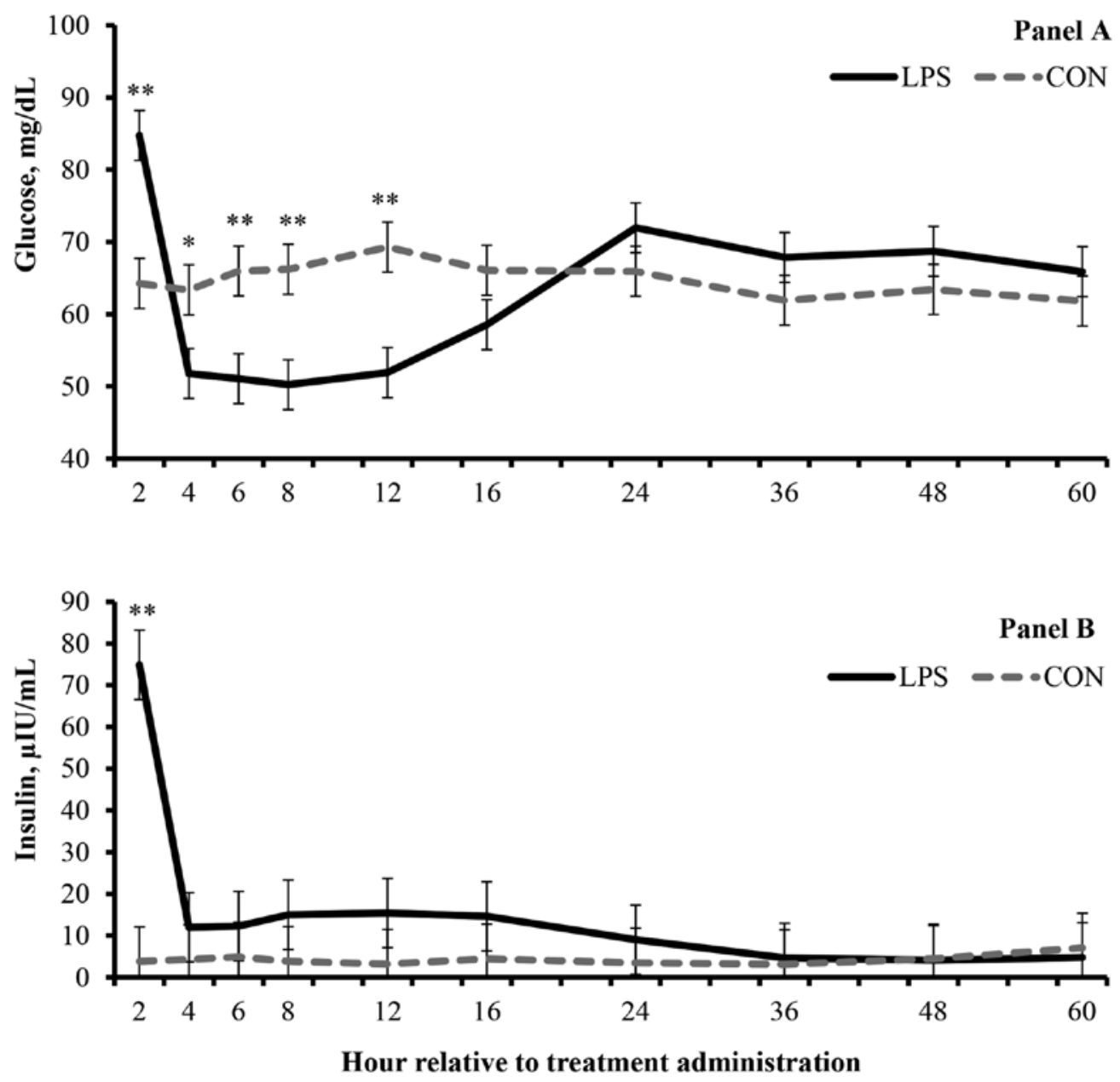

Figure 5. Plasma glucose (panel B) and insulin (panel C) concentrations of steers receiving 1) LPS $(n=4)=$ an intravenous (i.v.) bolus dose ( $0.5 \mu \mathrm{g} /$ $\mathrm{kg}$ of BW, diluted in $5 \mathrm{~mL}$ of $0.9 \%$ sterile saline) of bacterial lipopolysaccharide (Escherichia coli 0111:B4 [Sigma-Aldrich Corp., St. Louis, MO]) or 2) $\mathrm{CON}(n=4)=$ a $5-\mathrm{mL}$ i.v. injection of $0.9 \%$ sterile saline. Treatments were administered at h 0 . Values obtained prior to treatment application $(-2$ and $0 \mathrm{~h})$ served as covariates within each respective analysis. Treatment $\times$ hour interactions were detected $(P<0.01)$. Within hour; $* P \leq 0.05 ; * * P<0.01$.

Therefore, these compounds are expected to promptly reach the rumen, perhaps prior to decreased saliva flow due to reduced DMI and water intake on LPS administration (Adams and Kartchner, 1984). In turn, the rumen contains various immune cells such as Tand B-lymphocytes as well as myeloid lineage cells (Trevisi et al., 2014). The ruminal epithelium also expresses a variety of immunological receptors and cytokines, including Toll-like receptor 4 , IL-1 $\beta$ and IL10 , and caspase- 1 , which initiates the proinflammatory response (Trevisi et al., 2014). Moreover, rumen microbes express a variety of receptors that are believed to interact with mammalian hormones, particularly catecholamines (Freestone et al., 2008; Hughes and Sperandio, 2008). Although catecholamines were not evaluated herein, LPS administrations is known to sharply increase circulating concentrations of these hormones in cattle (Burdick et al., 2011), which, in turn, are also known to reach the saliva (Kennedy et al., 2001). Hence, it can be speculated that the neuroendocrine and inflammatory compounds elicited by
LPS administration reach the rumen and interact with ruminal and microbial cells. In turn, these compounds elicit host-microbiome interactions that transiently impair the ability of ruminal microbes to attach and degrade feed particles, as suggested by LPS effects on hay DM and NDF degradability (Table 2; Fig. 2). Supporting this rationale, Rath et al. (2016) and Samuelson et al. (2016) reported that microbial fermentation and nutrient digestibility were altered when exogenous epinephrine, norepinephrine, and cortisol were added to rumen fluid cultures.

In conclusion, LPS administration transiently reduced DMI in cattle via physiological, inflammatory, and acute-phase reactions that modulate gastrointestinal motility and satiety centers in the central nervous system, in addition to potential host-microbiome endocrine interactions that impaired hay DM and NDF degradability in the rumen. Although research is warranted to validate this latter outcome, results from this experiment provide novel knowledge that may serve as a foundation for future studies investigating the 

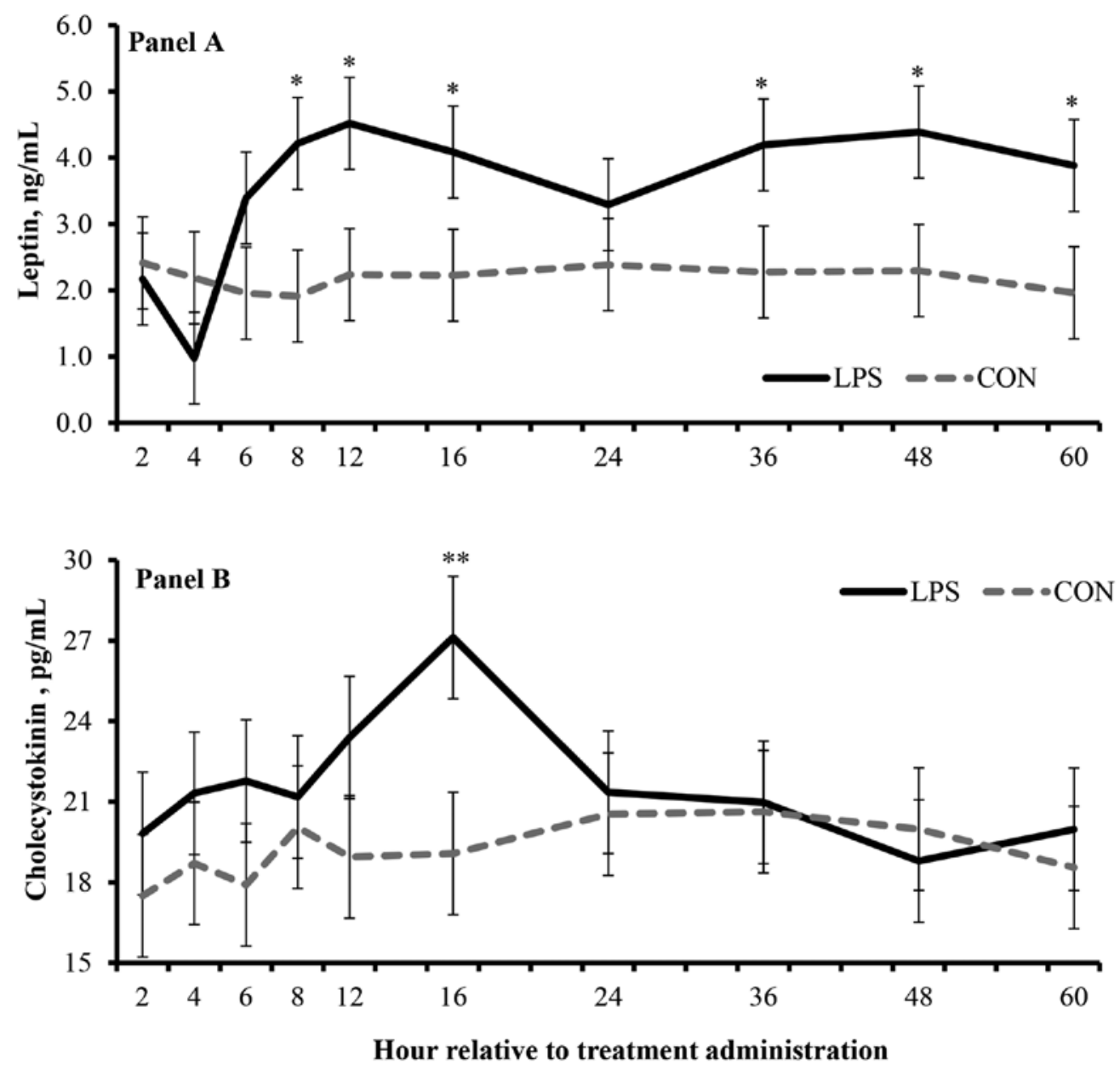

Figure 6. Plasma leptin (panel A) and cholecystokinin (panel B) concentrations of steers receiving 1) LPS $(n=4)=$ an intravenous (i.v.) bolus dose $(0.5 \mu \mathrm{g} / \mathrm{kg}$ of BW, diluted in $5 \mathrm{~mL}$ of $0.9 \%$ sterile saline) of bacterial lipopolysaccharide (Escherichia coli 0111:B4 [Sigma-Aldrich Corp., St. Louis, MO]) or 2) $\mathrm{CON}(n=4)=$ a $5-\mathrm{mL}$ i.v. injection of $0.9 \%$ sterile saline. Treatments were administered at h 0 . Values obtained prior to treatment application $(-2$ and $0 \mathrm{~h})$ served as covariates within each respective analysis. Treatment $\times$ hour interactions were detected $(P \leq 0.09)$. Within hour; $* P \leq 0.05 ; * * P<0.01$.

mechanisms by which stress and inflammation impact voluntary DMI in beef cattle.

\section{LITERATURE CITED}

Abbas, A. K., and A. H. Lichtman. 2007. Cellular and molecular immunology. 6th ed. Saunders Co., Philadelphia, PA.

Adams, D. C., and R. J. Kartchner. 1984. Effect of level of forage intake on rumen ammonia, $\mathrm{H}$, liquid volume and liquid dilution rate in beef cattle. J. Anim. Sci. 58:708-713. doi:10.2527/ jas1984.583708x

Allen, M. S. 2000. Effects of diet on short-term regulation of feed intake by lactating dairy cattle. J. Dairy Sci. 83:1598-1624. doi:10.3168/jds.S0022-0302(00)75030-2

Allen, M. S., B. J. Bradford, and M. Oba. 2009. The hepatic oxidation theory of the control of feed intake and its application to ruminants. J. Anim. Sci. 87:3317-3334. doi:10.2527/jas.20091779

Allison, C. D. 1985. Factors affecting forage intake by range ruminants: A review. J. Range Manage. 38:305-311. doi: $10.2307 / 3899409$
Andersson, A. K., M. Flodstrom, and S. Sandler. 2001. Cytokineinduced inhibition of insulin release from mouse pancreatic $\beta$-cells deficient in inducible nitric oxide synthase. Biochem. Biophys. Res. Commun. 281:396-403. doi:10.1006/ bbrc. 2001.4361

AOAC. 2006. Official methods of analysis. 18th ed. AOAC Int., Arlington, VA.

Araujo, D. B., R. F. Cooke, G. R. Hansen, C. R. Staples, and J. D. Arthington. 2010. Effects of rumen-protected polyunsaturated fatty acid supplementation on performance and physiological responses of growing cattle following transportation and feedlot entry. J. Anim. Sci. 88:4120-4132. doi:10.2527/jas.2009-2684

Bernabucci, U., P. Bani, B. Ronchi, N. Lacetera, and A. Nardone. 1999. Influence of short- and long-term exposure to a hot environment on rumen passage rate and diet digestibility of Friesian heifers. J. Dairy Sci. 82:967-973. doi:10.3168/jds.S00220302(99)75316-6

Burdick, N. C., J. A. Carroll, L. E. Hulbert, J. W. Dailey, M. A. Ballou, R. R. Randel, S. T. Willard, R. C. Vann, and T. H. Welsh Jr. 2011. Temperament influences endotoxin-induced changes in rectal temperature, sickness behavior, and plasma epinephrine concentrations in bulls. Innate Immun. 17:355-364. doi:10.1177/1753425910379144

Carroll, J. A., and N. E. Forsberg. 2007. Influence of stress and nutrition on cattle immunity. Vet. Clin. North Am. Food Anim. Pract. 23:105-149. doi:10.1016/j.cvfa.2007.01.003 
Carroll, J. A., R. R. Reuter, C. C. Chase Jr., S. W. Coleman, D. G. Riley, D. E. Spiers, J. D. Arthington, and M. L. Galyean. 2009. Profile of the bovine acute-phase response following an intravenous lipopolysaccharide challenge. Innate Immun. 15:81-89. doi: $10.1177 / 1753425908099170$

Cooke, R. F. 2017. Invited paper: Nutritional and management considerations for beef cattle experiencing stress-induced inflammation. Prof. Anim. Sci. 33:1-11. doi:10.15232/pas.201601573

Cooke, R. F., and J. D. Arthington. 2013. Concentrations of haptoglobin in bovine plasma determined by ELISA or a colorimetric method based on peroxidase activity. J. Anim. Physiol. Anim. Nutr. 97:531-536. doi:10.1111/j.1439-0396.2012.01298.x

Cooke, R. F., J. A. Carroll, J. Dailey, B. I. Cappellozza, and D. W. Bohnert. 2012. Bovine acute-phase response following different doses of corticotrophin-release hormone challenge. J. Anim. Sci. 90:2337-2344. doi:10.2527/jas.2011-4608

Crawley, J. N., and R. L. Corwin. 1994. Biological actions of cholecystokinin. Peptides 15:731-755. doi:10.1016/01969781(94)90104-X

Eizirik, D. L., S. Sandler, N. Welsh, L. Juntti-Berggren, and P. O. Berggren. 1995. Interleukin-1 B-induced stimulation of insulin release in mouse pancreatic islets is related to diacylglycerol production and protein kinase $\mathrm{C}$ activation. Mol. Cell. Endocrinol. 111:159-165. doi:10.1016/0303-7207(95)03561-K

Escribano, D., P. H. R. F. Campos, A. M. Gutiérrez, N. Le Floc, J. J. Cerón, and E. Merlot. 2014. Effect of repeated administration of lipopolysaccharide on inflammatory and stress markers in saliva of growing pigs. Vet. J. 200:393-397. doi:10.1016/j. tvj1.2014.04.007

Farooq, U., H. A. Samad, F. Shehzad, and A. Qayyum. 2010. Physiological responses of cattle to heat stress. World Appl. Sci. J. 8:38-43.

Fernández-Riejos, P., S. Najib, J. Santos-Alvarez, C. MartínRomero, A. Pérez-Pérez, C. González-Yanes, and V. SánchezMargalet. 2010. Role of leptin in the activation of immune cells. Mediat. Inflamm. 2010:568343. doi:10.1155/2010/568343

Foster, L. A., N. K. Ames, and R. S. Emery. 1991. Food intake and serum insulin response to intraventricular infusions of insulin and IGF-I. Physiol. Behav. 50:745-749. doi:10.1016/00319384(91)90012-D

Freestone, P. P., S. M. Sandrini, R. D. Haigh, and M. Lyte. 2008. Microbial endocrinology: How stress influences susceptibility to infection. Trends Microbiol. 16:55-64. doi:10.1016/j. tim.2007.11.005

Gilliam, G. G., B. C. Graham, J. W. Waggoner, K. A. DeAtley, L. Chen, S. L. Lodge-Ivey, and C. A. Löest. 2009. Rumen fermentation and passage rate of growing steers exposed to an endotoxin. Proc. - Am. Soc. Anim. Sci., West. Sect. 60:431-433.

Houseknecht, K. L., C. A. Baile, R. L. Matteri, and M. E. Spurlock. 1998. The biology of leptin: A review. J. Anim. Sci. 76:14051420. doi:10.2527/1998.7651405x

Hughes, D. T., and V. Sperandio. 2008. Inter-kingdom signaling: Communication between bacteria and their hosts. Nat. Rev. Microbiol. 6:111-120. doi:10.1038/nrmicro1836

Jacobs, B. M., J. F. Patience, M. D. Lindemann, K. J. Stalder, and B. J. Kerr. 2013. The use of a covariate reduces experimental error in nutrient digestion studies in growing pigs. J. Anim. Sci. 91:804-810. doi:10.2527/jas.2011-4868

Johnson, R. W. 1997. Inhibition of growth by pro-inflammatory cytokines: An integrated view. J. Anim. Sci. 75:1244-1255. doi:10.2527/1997.7551244x

Kennedy, B., E. Dillon, P. J. Mills, and M. G. Ziegler. 2001. Catecholamines in human saliva. Life Sci. 69:87-99. doi:10.1016/ S0024-3205(01)01111-0
Klasing, K. C., and D. R. Korver. 1997. Leukocytic cytokines regulate growth rate and composition following activation of the immune system. J. Anim. Sci. 75:58-67.

Lohuis, J. A. C. M., J. H. M. Verheijden, C. Burvenich, and A. S. J. P. A. M. van Miert. 1988. Pathophysiological effects of endotoxins in ruminants. Vet. Q. 10:109-116. doi:10.1080/0165217 6.1988.9694157

Mani, V., T. E. Weber, L. H. Baumgard, and N. K. Gabler. 2012. Growth and development symposium: Endotoxin, inflammation, and intestinal function in livestock. J. Anim. Sci. 90:14521465. doi:10.2527/jas.2011-4627

Matarese, G., S. Moschos, and C. S. Mantzoros. 2005. Leptin in immunology. J. Immunol. 174:3137-3142. doi:10.4049/jimmunol.174.6.3137

Matson, C. A., and R. C. Ritter. 1999. Long-term CCK-leptin synergy suggests a role for CCK in the regulation of body weight. Am. J. Physiol. 276:R1038-R1045.

Miller, C. S., J. D. Foley, A. L. Bailey, C. L. Campell, and R. L. Humphries. 2010. Current developments in salivary diagnostics. Biomarkers Med. 4:171-189. doi:10.2217/bmm.09.68

Nelson, D. L., and M. M. Cox. 2005. Lehninger principles of biochemistry. 4th ed. W. H. Freeman and Company. New York, NY.

NRC. 2000. Nutrient requirements of beef cattle. 7th ed. Natl. Acad. Press, Washington, DC.

Ørskov, E. R., and I. McDonald. 1979. The estimation of protein degradability in the rumen from incubation measurements weighted according to rate of passage. J. Agric. Sci. 92:499503. doi:10.1017/S0021859600063048

Plata-Salamán, C. R., and J. P. Borkoski. 1993. Centrally administered bacterial lipopolysaccharide depresses feeding in rats. Pharmacol. Biochem. Behav. 46:787-791. doi:10.1016/00913057(93)90202-5

Poore, M. H., J. A. Moore, and R. S. Swingle. 1990. Differential passage rates and digestion of neutral detergent fiber from grain and forages in 30, 60 and $90 \%$ concentrate diets fed to steers. J. Anim. Sci. 68:2965-2973. doi:10.2527/1990.6892965x

Qiu, X., J. D. Arthington, D. G. Riley, C. C. Chase Jr., W. A. Philips, S. W. Coleman, and T. A. Olson. 2007. Genetic effects on acute phase protein response to the stress of weaning and transportation in beef calves. J. Anim. Sci. 85:2367-2374. doi:10.2527/ jas.2006-843

Rahman, Z. A., N. Abdullah, R. Singh, and W. Sosroseno. 2010. Effect of acute exercise on the levels of salivary cortisol, tumor necrosis factor-alpha and nitric oxide. J. Oral Sci. 52:133-136. doi:10.2334/josnusd.52.133

Rath, L. L., K. L. Samuelson, A. L. Salazar, F. A. Lopez, E. J. Scholljegerdes, and C. A. Löest. 2016. Mammalian hormones associated with stress impact microbial fermentation of rumen fluid in vitro. Proc. - Am. Soc. Anim. Sci., West. Sect. 67:190-193.

Raun, N. S., and W. Burroughs. 1962. Suction strainer technique in obtaining rumen fluid samples from intact lambs. J. Anim. Sci. 21:454-457. doi:10.2527/jas1962.213454x

Reuter, R. R., J. A. Carroll, J. W. Dailey, B. J. Cook, and M. L. Galyean. 2008. Effects of dietary energy source and level and injection of tilmicosin phosphate on immune function in lipopolysaccharide-challenged beef steers. J. Anim. Sci. 86:19631976. doi: $10.2527 /$ jas.2007-0838

Robertson, J. B., and P. J. Van Soest. 1981. The detergent system of analyses and its application to human foods. In: W. P. T. James and $\mathrm{O}$. Theander, editors, The analysis of dietary fiber. Marcel Dekker, New York, NY. p. 123-158.

Rodrigues, M. C., R. F. Cooke, R. S. Marques, S. A. Arispe, D. H. Keisler, and D. W. Bohnert. 2015a. Effects of oral meloxicam administration to beef cattle receiving lipopolysaccharide administration or vaccination against respiratory pathogens. J. Anim. Sci. 93:5018-5027. doi:10.2527/jas.2015-9424 
Rodrigues, M. C., R. F. Cooke, R. S. Marques, B. I. Cappellozza, S. A. Arispe, D. H. Keisler, and D. W. Bohnert. 2015b. Effects of vaccination against respiratory pathogens on feed intake, metabolic and inflammatory responses in beef heifers. J. Anim. Sci. 93:4443-4452. doi:10.2527/jas.2015-9277

Samuelson, K. L., A. L. Salazar, L. L. Rath, J. B. Alford, E. R. Oosthyusen, S. L. Lodge-Ivey, D. M. Hallford, and C. A. Löest. 2016. Salivary cortisol concentrations affect rumen microbial fermentation and nutrient digestibility in vitro. Proc. - Am. Soc. Anim. Sci., West. Sect. 67:209-213.

Steiger, M., M. Senn, G. Altreuther, D. Werling, F. Sutter, M. Kreuzer, and W. Langhans. 1999. Effect of a prolonged low-dose lipopolysaccharide infusion on feed intake and metabolism in heifers. J. Anim. Sci. 77:2523-2532. doi:10.2527/1999.7792523x

Tajima, K., I. Nonaka, K. Higuchi, N. Takusari, M. Kurihara, A. Takenake, M. Mitsumori, H. Kailkawa, and R. I. Aminov. 2007. Influence of high temperature and humidity on rumen bacterial diversity in Holstein heifers. Anaerobe 13:57-64. doi:10.1016/j. anaerobe.2006.12.001

Teeter, R. G., and F. N. Owens. 1983. Characteristics of water soluble markers for measuring rumen liquid volume and dilution rate. J. Anim. Sci. 56:717-728. doi:10.2527/jas1983.563717x

Tizard, I. R. 2004. Vaccines and their production. In: T. Merchant, editor, Veterinary immunology. 7 th ed. Elsevier, Philadelphia, PA. p. 247-259.

Trevisi, E., M. Amadori, F. Riva, G. Bertoni, and P. Bani. 2014. Evaluation of innate immune responses in bovine forestomaches. Res. Vet. Sci. 96:69-78. doi:10.1016/j.rvsc.2013.11.011
Udén, P., P. E. Colucci, and P. J. Van Soest. 1980. Investigation of chromium, cerium, and cobalt as markers in digesta. Rate of passage studies. J. Sci. Food Agric. 31:625-632. doi:10.1002/ jsfa.2740310702

Van Soest, P. J., J. B. Robertson, and B. A. Lewis. 1991. Methods for dietary fiber, neutral detergent fiber, and nonstarch polysaccharides in relation to nutrition animal. J. Dairy Sci. 74:35833597. doi:10.3168/jds.S0022-0302(91)78551-2

Vendramini, J. M. B., L. E. Sollenberger, A. Adesogan, J. C. B. Dubeux Jr., S. M. Interrante, R. L. Stewart Jr., and J. D. Arthington. 2008. Protein fractions of Tifton 85 and rye-grass due to sward management practices. Agron. J. 100:463-469. doi:10.2134/agrojn12007.0143

Waggoner, J. W., C. A. Löest, J. L. Turner, C. P. Mathis, and D. M. Hallford. 2009. Effects of dietary protein and bacterial lipopolysaccharide infusion on nitrogen metabolism and hormonal responses of growing beef steers. J. Anim. Sci. 87:3656-3668. doi:10.2527/jas.2009-2011

Waldron, M. R., T. Nishida, B. J. Nonnecke, and T. R. Overton. 2003. Effect of lipopolysaccharide on indices of peripheral and hepatic metabolism in lactating cows. J. Dairy Sci. 86:34473459. doi:10.3168/jds.S0022-0302(03)73949-6

Warner, A. C. I., and B. D. Stacy. 1968. The fate of water in the rumen. I. A critical appraisal of the use of soluble markers. Br. J. Nutr. 22:369-387. doi:10.1079/BJN19680046

Weiss, W. P., H. R. Conrad, and N. R. St. Pierre. 1992. A theoretically-based model for predicting total digestible nutrient values of forages and concentrates. Anim. Feed Sci. Technol. 39:95110. doi:10.1016/0377-8401(92)90034-4 
Reproduced with permission of copyright owner.

Further reproduction prohibited without permission. 